УДК 811.161.2

DOI: 10.37026/2520-6427-2020-104-4-50-53
Леся ЗАВОДНА,

методист кабінету редакиійно-видавничої діяльності Рівненського ОІППО, магістр філології

\title{
СУРЖИК: МОВНА ПАТОЛОГІЯ ЧИ НОРМА УКРАЇНСЬКОГО СУСПІЛЬСТВА?
}

У статті схарактеризовано поняття українсько-російської двомовності, одним із наслідків якої $\epsilon$ змішане украӥнсько-російське мовлення - специфічне мовне явище, шьо дістало назву «суржику». Окреслено причини появи суржику. Виокремлено основні прояви суржику та приклади вживання слів-покручів.

Ключові слова: культура мови, суржик, двомовність, «слова-покручі».

The article deals with concept of Ukrainian-Russian bilingualism, one of the consequences of which is mixed Ukrainian-Russian speech - a specific linguistic phenomenon called «surzhyk». It has been outlined the reasons for the appearance of surzhyk. The main manifestations of surzhyk and examples of the use of twisting words are highlighted.

This phenomenon has become widely used among the Ukrainian population, especially young people, pupils, students, which especially gives the Ukrainian language the status of unprestigious (even more - hopeless) in terms of development, and is also of great concern.

The large explanatory dictionary of the modern Ukrainian language interprets the concept of «surzhyk» as follows: 1) a mixture of wheat and rye, rye and barley, barley and oats, etc.; flour from such a mixture; 2) elements of two or more languages, combined artificially, without observance of the norms of literary language; unclean language is an impoverished language, devoid of national color and expressiveness.

Among the reasons for the appearance of surzhyk is the lack of six language skills: 1) the amount of vocabulary; 2) correctness of language; 3) subconscious operation of language (automatism); 4) language creation (ability to create neologisms); 5) functional language skills (emotional); 6) imagery of language.

The main manifestations of surzhyk are: the use of russisms instead of normative Ukrainian equivalents; ukrainianized forms of Russian numerals; ukrainianized forms of Russian verbs; mixing Ukrainian and Russian forms of indefinite pronouns; formation of the highest degree comparison of adjectives and adverbs on the model of the Russian language; words and expressions copied from Russian; softened and soft pronunciation of consonants before "e» and «y» in originally Ukrainian and loanwords; non-normative use of grammatical forms of Ukrainian language.

Key words: language culture, surzhyk, bilingualism, «twisting words».

\author{
Начії вмирають не від інфаркту, \\ спочатку їм відбирає мову. \\ Ліна Костенко
}

Постановка проблеми. Українська мова впродовж багатьох століть була поставлена в такі умови, що можна лише дивуватися, як вона взагалі вижила i збереглася. «Політика асиміляції неросійських народів, розпочата ще за самодержавства» $[14$, с. 8], яка непосильним тягарем лежала на ній (згадаймо хоча б славнозвісні: указ Петра I 1720 р. про заборону друкування книг українською мовою; секретну інструкцію 1764 р. Катерини II генерал-прокуророві Сенату, де йшлося про те, що «Малая Россия, Лифляндия $u$ Финляндия - провинции..., [которые] ... надлежит легчайшими способами привести к тому, чтоб они обрусели ...»; закриття недільних шкіл 1862 р.; Валуєвський циркуляр 1863 р., який проголошував, що «ніякої української мови не було, немає і бути не може», й зрештою Емський указ 1876 р. про «заборону ввозити до Росї будь-які книжки і брошури, написані «малоросійським наріччям», друкувати оригінальні твори та переклади украӥнською мовою, влаштовувати сиенічні вистави, друкувати украӥнські тексти до нот і виконувати україномовні музичні твори»), в радянський період набула ще відвертіших форм.

Зрозуміло, що таке кількасотрічне приниження української мови, «обмеження сфер ії використання, руйнація іiі основ, втручання у внутрішні закони іiі розвитку, здійснення численних «чисток» на заборону певних слів і висловів перетворило нашу мову із самодостатньої системи на жертву тоталітарного суспільства...» [14, с. 8], а відповідно насаджування російської не могло не позначитися на усному та писемному мовленні ії носіїв. Українська мова навіть там, де вона активно функціонувала, зазнала такого негативного впливу російської, що перетворилася на «язичіє», мішанину українських та російських слів, кальок, так званих «мовних покручів», які утворилися на базі цих двох мов. Як зауважує сучасний лексикограф і перекладач Тарас Береза, «у битві за мову, ми програємо сьогодні двом монстрам - англомовній глобалізації та русифікації. Вони нищать нашу мовну автентичність. Люди не свідомі того, що мова маліє, зменшується іiі словниковий запас. Українська перетворюється на суто «побутову». Це вже не та вишукана мова, це просто засіб для порозуміння між людьми» [4]. 
Сьогодні мовну ситуацію в Україні головним чином характеризує українсько-російська двомовність, одним із наслідків якої є змішане українсько-російське мовлення - специфічне мовне явище, що дістало назву «суржику», який, на думку І. Ціхоцького, «переріс стилістичний діапазон ужиткового мовлення i впевнено проникає в літературні та музичні тексти, мову телебачення і преси, чому активно сприяє постмодерна рецепція дійсності в українській мистецькій парадигмі та шоу-бізнесі» [15], й, на жаль, перетворюється на неабияку проблему українського суспільства, привертаючи до себе щораз більше уваги.

Аналіз наукових досліджень і публікацій. Питанням суржику присвячено величезну кількість досліджень українських мовознавців.

Так, ще Б. Антоненко-Давидович у праці «Як ми говоримо» подає найбільш вдале, на наш погляд, пояснення суржику та описує загрозу, що він несе: «Недобре, коли людина, не знаючи гаразд української чи російської мови, плутає обидві мови, перемішує слова, відмінює слова однієї мови за граматичними вимогами другої мови, бере якийсь притаманний саме цій мові вислів і самотужки, живосилом тягне його в іншу мову Так утворюється мовний покруч» [3]. Відома мовознавиця О. Сербенська, книга якої «Антисуржик» [2] є чи не найбільш ключовою у питанні дослідження суржику як мовного явища, одна $з$ перших, хто підтримала та розвивала погляди Антоненка-Давидовича «на субмову як здеградовану під тиском русифікації форму українського мовлення» $[11$, с. 93].

Однозначного тлумачення цього мовного явища на сьогодні немає. Зокрема, мовознавці потрактовують суржик і як форму просторіччя (В. Труб [13]), і як субмову (Л. Масенко [8]), і як піджин (Н. Дзюбишина-Мельник [6]), і як напівмовність (Б. Ажнюк [1]), і як «недопереклад» (В. Радчук [10]), і як окрему категорію, що впливає на мовну політику в державі (М. Мозер [9]), і як сукупність явищ мовленнєвого рівня (О. Тараненко [12]).

Утім, спільним для всіх дослідників є сприйняття суржику як загалом негативного явища. Адже, як стверджує відома дослідниця Л. Масенко, «суржик нищить узус (практичну спонтанну норму) української мови і відриває ії від літературної основи» [9, с. 125].

Однак, незважаючи на досить значну кількість праць, що стосуються даного питання, проблема поширення суржику в мові не тільки не втрачає своєї актуальності, а й, навпаки, перетворюється на «сумне» явище, а отже, потребує подальшого аналізу та дослідження.

Мета статті - окреслити проблему суржику як негативного явища в українській мові; на прикладі численних слів-покручів продемонструвати наявність суржику в нашому повсякденному мовленні.

Виклад основного матеріалу. Мовне явище, що одержало назву «суржик», належить до специфічної форми побутування мови в Україні.

Великий тлумачний словник сучасної української мови так трактує поняття «суржик»: 1) суміш зерна пшениці й жита, жита й ячменю, ячменю й вівса тощо; борошно з такої суміші; 2) елементи двох або кількох мов, об'єднані штучно, без додержання норм літературної мови; нечиста мова, збіднена мова, позбавлена національного колориту i виразності [5, с. 1217]. Відповідно М. Мозер зі свого боку стверджує, що «перше, головне переносне значення слова, а саме «людина мішаного походження», засвідчено в словнику Бориса Грінченка 1907-1909 років. Значення, яке стосується мови, очевидно виникло пізніше. В енциклопедичній статті це значення окреслено як «ненормативне індивідуальне мовлення певної особи та соціолект певних верств населення, що будуються на основі змішування, інтерференції елементів двох і більше мов» [9, с. 29].

Дане явище набуло широкого вжитку серед українського населення, передусім молоді, школярів, студентів, що особливо впливає на престижність нашої мови та безперспективність іiі розвитку, викликаючи неабияке занепокоєння.

Які ж причини появи суржику? Український мовознавець, доктор філологічних наук Богдан Ажнюк переконує, що це відбувається через брак шести мовних навичок: 1) обсягу словникового запасу; 2) коректності мови; 3) підсвідомого оперування мовою (автоматизму); 4) мовотворчості (здатності творити неологізми); 5) функціонального володіння мовою (наприклад, емотивного); 6) образності мови [1].

Зважаючи на викладене вище, з'ясуємо, де ж сучасна молодь (і не лише вона!) може «підхопити» суржик:

По-перше, на це неабияк впливає виховання в родині, коли батьки (а саме вони мають найбільший вплив на успішне формування мовлення дитини), не приділяючи належної уваги своєму мовленню та впевнено вживаючи суржикомовні слова, сприяють тому, що дитина не лише повторює, а й починає говорити тією мовою, яку сприймає на слух, фактично спілкуватися суржиком і думає, що так насправді правильно.

По-друге, носіями суржику стають люди, які недосконало володіють як українською, так і російською мовами і не завжди зважають на правильність вживання україномовної лексики. Вони 3 легкістю відмінюють слова однієї мови за правилами іншої, будують словосполучення та речення всупереч моделям рідної мови, вживають слова в нехарактерній для української мови граматичній формі. Будь-який психолог підтвердить, що така спотворена мова «отупляє» людину, робить іiі мислення примітивним.

По-третє, до суржику-гри охоче вдається сучасна ОСВІЧЕНА! молодь, зокрема студенти, коли хоче увійти в інший мовний образ, розширити діапазон власних мовних варіацій. Соціологічні дослідження переконують, що молоді люди вдаються до суржику частіше, ніж люди середнього та похилого віку, які схильні вважати його ознакою низького рівня мовної культури. Прекрасно володіючи іншими мовними кодами, молодь воліє використовувати суржик, щоб отримати задоволення від власного мовлення, бо їй так цікаво («прикольно»).

По-четверте, розповсюдженню суржикомовних слів значною мірою сприяють сучасні теле-, радіо- та медіапростір, що здатні стирати кордони між правильним і неправильним, адже тут людина почувається вільною у власних думках. Мова в інтернет-просторі, зокрема в соціальних мережах Фейсбук, Твітер, Інстаграм, спрощується, 
порушується пунктуація, синтаксис, а граматика не відіграє важливої ролі, натомість посилюється емоційність мови; як наслідок - з'являється низка суржикомовних слів.

Таким чином, беручи за основу дослідження А. І3майлової [7], та доповнивши його низкою власних знахідок, основними проявами суржику вважаємо:

- ужсивання русизмів замість нормативних українських відповідників: больніца (лікарня), будто (нібито), вообще (зовсім), вопщем (отож), вот (ось), в смиле (в сенсі), всєгда (завжди), всі равно (все одно), вмєсто (замість), вроді (наче), гарбушка (окраєиь), да (так), даже (навіть), дєвочкі (дівчатка), допустім (припустимо), до встрєчі (до зустрічі), єслі (якщо), єсть (є), здрастує (добридень), імєнно (саме), йолка (ялинка), карочє (одним словом), крєпкій (міцний), кстаті (до речі), ладно (нехай), мєжду (між), нєт (ні), нє нада (не потрібно), навєрно (мабуть), намьок (натяк), напрімєр (наприклад), носки (икарпетки), очєнь (дуже), парадне (під'їз), потом (потім), предохранітель (запобіжник), предсідатєль (голова), почтальйон (листоноша), рядом (поруч), слідуючий (наступний), самальот (літак), стелька (устілка), mina (типу), тоже (також), тоїсть (тобто), туда (туди), щчас (зараз), харашо (добре), прям (справді), постоянно (постійно), послєдній (останній), форточка (кватирка), уборка (прибирання), чуть-чуть (трохи), шо попало (будь щцо), шо такоє (що таке), щас / січас (зараз), та ін.;

- «українізовані» форми російських дієслів: уїхав (поїхав), підскажіть (підкажіть), уволився (звільнився), поняв (зрозумів), получив (отримав), щуитати (залежно від контексту - вважати або рахувати), отдав (віддав), здєлав (зробив), длився (тривав), ростроївся (засмутився), отключив (відімкнув), зарабатує (заробляє), підозріваю (підозрюю), обіжається (ображається), тренєруваться (тренуватися), жалію (шкодую), панімать (розуміти), не трогай (не зачіпай), догадаться (здогадатися), розшитатися (розрахуватися), заболів (захворів), получається (виходить), помню (пам'ятаю), позориться (соромитися), прибратися (замість прибрати) та ін.;

- «украӥнізовані» форми російських числівників: первий / перва (перший / перша), вторий / втора (другий / друга) та ін.;

- змішування украӥнських $і$ російських форм невизначених займенників: хто-то (хтось), иото (щось), як-то (якось), які-то (якісь), який-то (якийсь), чого-то (чомусь, чогось), кой-шо (щось), кой-які (якісь) та ін.;

- порушення дієслівного керування, вживання прийменників $і$ відмінків за зразком російськоі мови: по вулииям (вулицями), на російській мові (російською мовою), зошит по біології (зочит з біології) та ін.;

-утворення найвищого ступеня порівняння прикметників і прислівників за зразком російськоі мови: самий главний (найголовніший), саме важне (найважливіше), самий лучший (найкращчии), саме тверде (найтвердіме) та ін.;

- утворення від украӥнських дісслів активних дієприкметників за російським зразком: купивиий (той, що купив), прийшовший (той, що прийшов), зробивший (той, щчо зробив) та ін.;
- слова і вирази, кальковані з російської: міроприємство, прийняти міри, прийняти участь, так як, в якості, бувший у користуванні, на протязі, повістка дня, під відкритим небом та ін.;

-у вимові - це редукція ненаголочених голосних, оглушення дзвінких приголосних, заміна «дж» і «дз» на «ж) і «з», також відсутність чергування «к/uџ», зсув наголосу за зразком російської мови: када, розгаварювать, росписуваться, звонять, нахожуся, в восьмирічкі; відсутність чергування «о/i» або «е/i»: корова / коров, голова / голов (замість - корів, голів);

- пом'якшена ім'яка вимова приголосних перед "е» та «и" у споконвічно українських та запозичених словах (в українській мові приголосні перед $e$ та $u$ не пом'якшуються): сЄло, сЄстра, зІма, дІрЄктор, лЄгСнда, калЄндар, кІиеня, ідЄал, манСж, тЄлЄграма, манЄвр, дІспут, тІгр, чСрЄпаха, бібліатЄка, канСшно,інтєрСсно, проблСми;

- ненормативне використання граматичних форм украӥнської мови, що призводить до ії деформації: маємо вільні номера (замість - номери), підготуйте паспорта (замість - паспорти), як доїхати до вокзала (замість - вокзалу), працюю чотири місяия в рік (замість - місяиі на рік), у тисячу (замість тисяча) дев'ятсот n'ятому роиі.

Отже, на жаль, слова-покручі оточують нас скрізь і всюди. Вони немовби «невидимі тіні» переслідують нас щодня у транспорті, в магазинах, у рекламних оголошеннях, у соціальних мережах і засобах масової інформації, наприклад:

\section{У транспорті}

1) Рука водія «маршрутки» - на кермі, погляд зосереджений вдалечінь, а вуста вигукують: «Заберіть «здачу!» (решту), та ще й цілих 10 «гривнів» (гривень). Нарешті кінцева зупинка - і він оголошує: «Конєчна, ж/д вокзал!» (кіниева, залізничний вокзал).

2) У тролейбусі зранку крізь натовп сонних пасажирів продирається кондукторка, голос якої здатний розбудити кожного пасажира, а фраза «Хто ще не має білєтіка?» (квитка) проникає до самого серця. Незабаром зупинка і хтось вже гукає 3 натовпу: «На слідуючій остановці виходите?» замість сказати гарно українською: «На наступній зупинциі виходите?».

\section{У супермаркеті}

До каси - довжелезна черга. Молода касирка енергійно вигукує: «Пакєтік (пакет) брать будете?». Розраховуючи, запитує: «Мєлкіми (дрібними грошима) дасте, бо здачу (решту) не зможу здати».

У рекламних оголошеннях (орфографію й пунктуацію збережено)

- Здам в аренду бітономімалку.

- Студент! Хочешь зарабатьвать! Звони! Хочеш крутити справжній кермо, а не джойстик? 3водити дівчину не у фастфуд, а в ресторан7 Набридло тинятися без діла? Совмешай з навчанням або основною роботою. Немає досвіду - Безкоштовно ми навчимо. Заробляй від 5000 і Більше!

- С робота головою! дізнайся умова! дзвони! вік 21-38 лет. предпочтение чоловікам відповідальним!!!

- Шукаю роботу бензопилкою!

А ось на такі оголошення можна натрапити в міській «маршрутці» Рівного та на сайтах рівненських оголошень: 


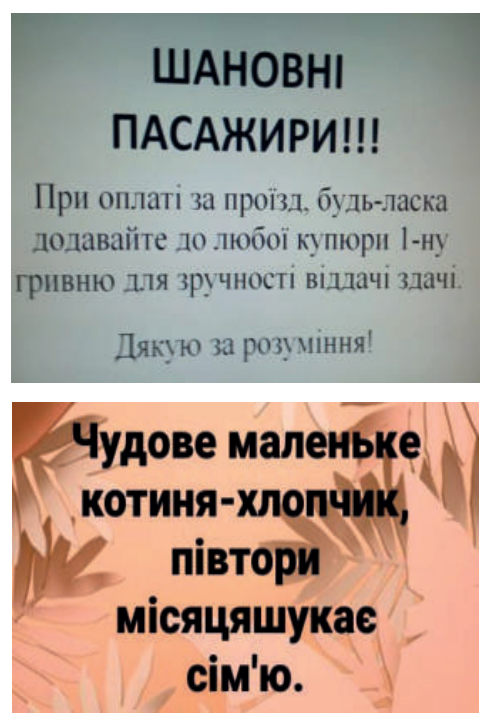

То ж чому українці загалом і сучасна молодь зокрема не розмовляють гарною українською мовою, вживаючи суржик? Відповідь проста:

1. Знайомство з медіапростором сучасні діти, на жсаль, розпочинають не з української продукції (зазвичай це російськомовна анімація), внаслідок чого російські слова складають основу дитячого мовлення.

2. Нам зручніше послуговуватися покручами: канєшно, вєздє, як діла, отута, образованіє тощо.

3. НЕ круто / украӥнська не модна / не с мовою бізнесу: левова частка популярних ютуб-каналів та потужних освітніх майданчиків доступні винятково російською.

4. И так паймут / какая разница...

5. Украӥнською багато не заробиш...

Але при цьому кожен без угаву торочить: «Мова мас значення!", "Мова - душа народу!", "Без мови немає нації!" [4].

Як маємо чинити в даному випадку - залежить особисто від кожного. Адже це не перевага вчених-лінгвістів, письменників чи вчителів-філологів. Це не тільки ознака, а насамперед обов'язок будь-якої культурної особистості.

Правильно й чисто говорити рідною мовою може кожен, було б лише бажання. Для цього потрібно багато читати, але не будь-чого, а гарно написаних, iз добрим перекладом книг. А також, за порадою Максима Рильського, «не боятися заглядати у словник», бо саме словники, насправді, є добрими нашими порадниками й помічниками на нелегкому шляху до досконалості мови.

Висновки. «Краса і сила рідної мови, - за влучним висловом Бориса Антоненка-Давидовича, - таїться не в іiї фонетичних перевагах i, поготів, не в іiі привілейованому зверхньому становищі супроти інших мов, якщо це десь трапляється, а в здатності впливати на почуття людини, будити в ній хороші благородні почуття, змушувати бриніти найтонші струни людської душі» [3].

Тож докладімо всіх зусиль, щоб наша рідна мова була «чистіша від сльози», а для цього потрібно зовсім небагато - якомога більше читати українською, мислити українською, не боятися говорити українською, а ще - працювати над помилками, дбати про чистоту нашої мови, «виполюючи» зі свого щоденного мовного вжитку «бур'ян», ім'я якому - суржик.
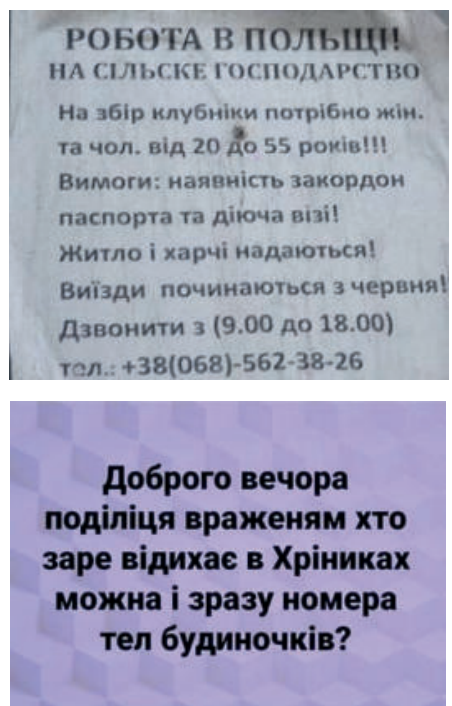

\section{СПИСОК ВИКОРИСТАНОЇ ЛІТЕРАТУРИ}

1. Ажнюк Б. М. Мовна єдність нації : діаспора й Україна. Київ : Рідна мова, 1999. 450 с.

2. Антисуржик. Вчимося ввічливо поводитись i правильно говорити / за заг. ред. О. Сербенської. Львів, 1994. - 152 с.

3. Антоненко-Давидович Б. Як ми говоримо. Київ : Либідь, 1991. Вид. 4-е. 256 с.

4. Береза Т. У битві за мову ми програємо двом монстрам. URL: https:/gazeta.ua/articles/sogodennya/_ubitvi-za-movu-mi-prograyemo-dvom-monstramslovnikar/957245 (дата звернення: 12.08.2020).

5. Великий тлумачний словник сучасної української мови. 7-е вид, допов. / уклад. і голов. ред. В. Т. Бусел. Київ ; Ірпінь : Перун, 2009. 1736 с.

6. Дзюбишина-Мельник Н. Суржик і суржикізми : стилістичні ресурси. Наукові записки НаУКМА. Київ : Вид-во НаУКМА, 2010. Т. 111. Філологічні науки. С. 16-20.

7. Ізмайлова А. Суржик і культура мовлення. URL: https://kpi.ua/surzhik (дата звернення: 03.09.2020).

8. Масенко Л. Суржик: між мовою і язиком. 2-е вид, змінене і допов. Київ : Києво-Могилянська академія, 2019. 202 с.

9. Мозер М. «Суржик» чи «Суржики»? Українська мова. 2016. № 1. С. 27-54. URL: file:///C:/Users/ $\% \mathrm{D} 0 \% 9 \mathrm{~B} \% \mathrm{D} 0 \% \mathrm{~B} 5 \% \mathrm{D} 1 \% 81 \% \mathrm{D} 1 \% 96 \% \mathrm{D} 1 \% 87 \% \mathrm{D} 0 \%$ BA\%D0\%B0/Downloads/Ukrm_2016_1_5\%20(1).pdf) (дата звернення: 03.09.2020).

10. Радчук В. Суржик як недопереклад. Украӥнська мова та література. 2000. № 11 (171). С. 11-12.

11. Сербенська О. Суржик: «низька мова», безлад чи мовна патологія? Мовні конфлікти і гармонізація суспільства. Київ, 2002. С. 93.

12. Тараненко О. Українсько-російський суржик: статус, тенденції, оцінки, прогнози. Мовознавство. 2008. № 1. С. 14-30.

13. Труб В. Явище «суржику» як форма просторіччя в ситуації двомовності. Мовознавство. 2000. № 1. C. 46-57.

14. Фаріон I. Мовна норма: знищення, пошук, віднова (культура мовлення публічних людей) : монографія. Івано-Франківськ : Місто НВ. 2013. 332 с.

15. Ціхоцький I. Антисуржик: у пошуках мовної ідентичності. Теле- та радіожурналістика. 2012. Вип. 11. С. 289.

Дата надходження до редакиії: 16.10.2020 p. 